\title{
Association between Tooth Agenesis and Skeletal Malocclusions
}

\author{
Ana Maria Guerra Costa1, Mariana Trevizan', Mírian Aiko Nakane Matsumoto1, Raquel Assed \\ Bezerra da Silva ${ }^{1}$, Lea Assed Bezerra da Silva ${ }^{1}$, Karla Carpio Horta ${ }^{1}$, Fabio Lourenço Romano ${ }^{1}$, \\ Paulo Nelson-Filho', Erika Calvano Küchler ${ }^{1}$
}

${ }^{1}$ Department of Pediatric Dentistry, Ribeirão Preto Dental School, USP - University of São Paulo, Ribeirão Preto, São Paulo, Brazil.

\section{Corresponding Author:}

Erika Calvano Küchler

Department of Pediatric Dentistry, School of Dentistry of Ribeirão Preto

University of São Paulo - USP

Avenida do Café s/n, Monte Alegre, 14040-904, Ribeirão Preto, São Paulo

Brazil

Phone: +55 1633154057

Fax: +55 1636330999

E-mail: erikacalvano@gmail.com

\begin{abstract}
Objectives: The aim of this study was to evaluate the association between tooth agenesis and skeletal malocclusions in Brazilian non-syndromic orthodontic patients.

Material and Methods: Pretreatment orthodontic records of 348 patients of both genders and with various skeletal malocclusions were examined. Tooth agenesis was evaluated in panoramic radiographs. Angular measurements were taken from lateral cephalometric radiographs to classify the patient's malocclusion as skeletal Class I, Class II and Class III. Subjects were divided into 2 groups, "with tooth agenesis" and "without tooth agenesis". Chi-square or Fisher exact test was used to compare categorical data. ANOVA with Tukey's post-test was used for means comparisons. An alpha of 5\% was established. Results: From 348 analysed patients, 28 presented tooth agenesis. There was no difference between genders $(\mathrm{P}=0.27)$ nor mean age $(\mathrm{P}=0.16)$. The most prevalent skeletal malocclusion was Class I $(63.11 \%)$, followed by Class II $(25.94 \%)$, and Class III (10.95\%). The mean of congenitally missing teeth was 1.3 (SD 0.13). Thirteen subjects had premolar agenesis, 13 upper lateral incisor agenesis, 4 lower incisor agenesis and 2 molars agenesis. The group with tooth agenesis presented A pointnasion-B point (ANB) angle smaller (1.66 [SD 2.52]) than the group without tooth agenesis (2.86 [SD 2.49]) $(\mathrm{P}=0.01)$. ANB angle had a negative correlation with the number of congenitally missing teeth $(\mathrm{P}=0.039 ; \mathrm{r}=-0.39)$.

Conclusions: Tooth agenesis is associated with a smaller A point-nasion-B point angle and is negatively correlated with the number of congenitally missing teeth.
\end{abstract}

Keywords: anodontia; birth defects; tooth abnormalities.

Accepted for publication: 26 June 2017

To cite this article:

Costa AMG, Trevizan M, Matsumoto MAN, da Silva RAB, da Silva LAB, Horta KC, Romano FL, Nelson-Filho P, Küchler EC.

Association between Tooth Agenesis and Skeletal Malocclusions

J Oral Maxillofac Res 2017;8(2):e3

URL: http://www.ejomr.org/JOMR/archives/2017/2/e3/v8n2e3.pdf

doi: $10.5037 /$ jomr.2017.8203 


\section{INTRODUCTION}

Tooth agenesis (or congenitally missing tooth) is one of the most common congenital anomaly in humans. It is characterized by developmental absence of one or more primary or permanent teeth. Permanent tooth is more commonly affected than primary tooth $[\underline{1}, \underline{2}]$. The most common absent teeth are third molars, followed by premolars and upper lateral incisors $[\underline{3}, \underline{4}]$. Reports on the overall prevalence of permanent tooth agenesis vary substantially. In Caucasians, the reported frequency of tooth agenesis, excluding third molars, range from $5.5 \%$ in European population, $3.9 \%$ in North American population and $6.3 \%$ in Australian population [ $[$ ] .

Tooth agenesis can be classified into syndromic and non-syndromic. Syndromic tooth agenesis refers to complex developing syndromes associated with a congenitally missing tooth or teeth [6]. More than 60 syndromes catalogued in Online Mendelian Inheritance in Man (OMIM) are associated with agenesis. Non-syndromic tooth agenesis involves a congenitally missing tooth in an isolated form, without an association with any other major birth defects [7].

In the past few years, some studies have evaluated the association between specifics craniofacial patterns and non-syndromic tooth agenesis [8-18], however, the results pertaining to skeletal malocclusions with tooth agenesis are controversial. Some authors did not find a significant association between tooth agenesis and malocclusions $[\underline{10}, \underline{15}, \underline{18}]$, while other authors observed association or tendency with skeletal Class II malocclusion $[\underline{13}, \underline{14}, \underline{16}]$. On the other hand, other studies observed that tooth agenesis is associated or tendency with skeletal Class III malocclusion $[\underline{8}, \underline{9}, 11,17]$. Therefore, the aim of this study was to evaluate if non-syndromic tooth agenesis is associated with skeletal malocclusions in Brazilian nonsyndromic pre-orthodontic patients.

\section{MATERIAL AND METHODS Sample}

The study protocol was reviewed and approved by the Ethics Committee of the School of Dentistry Ribeirão Preto, University of São Paulo (CAAE 50765715.3.0000.5419). Informed consent was obtained from all participating individuals or parents/legal guardians during the first orthodontic consultation.

Pre-orthodontic treatment panoramic and lateral cephalometric radiographs from patients treated from 2000 to 2015, at the Orthodontic clinic of the School of Dentistry of Ribeirão Preto - University of São Paulo, were evaluated.

The sample consisted of 348 untreated individuals, self-reported Caucasian, aged 8 to 42 years with various skeletal malocclusions. The exclusion criteria included patients younger than 8 years old, not selfreported Caucasian, with craniofacial syndromes or chronic conditions, history of facial trauma or facial surgery, previous orthodontic treatment, records with missing radiographs, and radiographs with poor quality or missing landmarks. One case with cleft lip and palate was found and excluded from the sample.

\section{Determination of tooth agenesis phenotype}

Cases of tooth agenesis were clearly evident from the panoramic radiographs alone. All panoramic radiographs were examined by the same professional (AMGC) using the same protocol $[\underline{3}, 4]$.

The inclusion criterion was that at least one permanent tooth was affected, excluding third molars. Tooth agenesis was defined based on the age of subjects and when initial tooth formation should be visible in the radiographs [3,4]. In accord with the mentioned criteria, second premolar agenesis was only considered on patients older than 8 years old [4].

\section{Determination of skeletal malocclusion}

Pretreatment lateral cephalometric radiographs were hand traced and measured by two orthodontists previously trained (MANM and FLR, inter-observer agreement 0.95).

The following landmarks were used for cephalometric analysis: point A (A), point B (B), sella (S), and nasion (N). Sagittal skeletal discrepancies were assessed using angular measurements: angle between sella, nasion and subspinale point A (SNA), angle between sella, nasion and supramentale point $\mathrm{B}$ (SNB), and angle between subspinale point A, nasion and supramentale point B (ANB). Then, the total sample was classified as skeletal Class I malocclusion $\left(0^{\circ}<\right.$ ANB $\left.<4^{\circ}\right)$, skeletal Class II malocclusion (ANB $\geq 4^{\circ}$ ), and skeletal Class III malocclusion $\left(\mathrm{ANB} \leq 0^{\circ}\right)$.

\section{Statistical analysis}

Data were analysed using Epi Info 7 and Graph Pad Prism 5.0a. The Shapiro-Wilk test was used to verify the normality of the data. The comparisons were performed between the groups 'with tooth agenesis' 
and 'without tooth agenesis'. Tooth agenesis evaluation was performed according to the type of congenitally missing teeth (upper lateral incisors, premolars and others congenitally missing teeth) and according to the affected arch (maxillary and mandible). The group without tooth agenesis was used as a comparison group.

Odds ratio calculations and Chi-square or Fisher's exact tests were used to evaluate the association between tooth agenesis and skeletal malocclusion. Parametric data were expressed as mean and standard deviation (M [SD]). To compare the difference between the means of the angular measurements, t-test was used. The Pearson coefficient test was used to evaluate the degree of the correlation between number of congenitally missing teeth and angular measurements. The established alpha was 5\%.

\section{RESULTS}

Three hundred forty-eight subjects were evaluated. The mean age was 15.2 (6.69) years. Twenty-eight $(8.04 \%)$ patients presented at least one tooth agenesis.

Table 1. Characteristics of the studied population

\begin{tabular}{c|c|c|c}
\hline Variable & $\begin{array}{c}\text { Without tooth } \\
\text { agenesis }\end{array}$ & $\begin{array}{c}\text { With tooth } \\
\text { agenesis }\end{array}$ & P-value \\
\hline Mean age (SD) & $15.35(6.87)$ & $13.5(3.81)$ & 0.16 \\
\hline Gender, N (\%) & \multicolumn{3}{|l}{} \\
\cline { 1 - 3 } Male & $129(90.85)$ & $13(9.15)$ & \multirow{2}{*}{0.27} \\
\hline Female & $190(92.68)$ & $15(7.32)$ & \\
\hline
\end{tabular}

No statistically significant $\mathrm{P}>0.05$ (t-test and Chi-square test). $\mathrm{SD}=$ standard deviation; $\mathrm{N}=$ number.
Forty-five teeth were congenitally missing. The number of congenitally missing teeth ranged between 1 to 4 and the mean was $1.3(0.13)$. Thirteen $(3.75 \%)$ subjects had premolar agenesis, 13 (3.75\%) upper lateral incisor agenesis, $4(1.15 \%)$ lower incisor agenesis and $2(0.58 \%)$ molars tooth agenesis.

The characteristics of the studied population are presented in the Table 1 . The mean age and gender distribution were not different between patients with and without tooth agenesis $(\mathrm{P}>0.05)$.

Two hundred nineteen $(63.11 \%)$ patients presented skeletal Class I malocclusion, 90 (25.94\%) patients skeletal Class II malocclusion, and 38 (10.95\%) patients skeletal Class III malocclusion. The distribution of tooth agenesis subgroups according to the skeletal malocclusion is presented in the Table 2 . Skeletal Class III malocclusion was associated with premolar tooth agenesis $(\mathrm{P}=0.039)$.

Table 3 demonstrates the mean of the cephalometric measurements SNA, SNB and ANB according to the groups. The ANB measurement was smaller in the group with tooth agenesis $(\mathrm{P}=0.01)$.

The cephalometric measurements SNA, SNB and ANB angles were also evaluated according to the affected arch. There was no statistical difference among the groups $(\mathrm{P}>0.05)$.

The evaluation according to the type of congenitally missing tooth demonstrated a statistical difference in the ANB angle for the premolar tooth agenesis $(\mathrm{P}=0.01)$. The mean ANB measure in the premolar tooth agenesis group was 1.11 (2.79).

The correlation between the number of congenitally missing teeth and the SNA, SNB and ANB angles were performed. There was no correlation between SNA and SNB angles and the number of congenitally

Table 2. Tooth agenesis subgroups' distribution according to the skeletal profile

\begin{tabular}{l|c|c|c|c}
\hline \multirow{2}{*}{ Groups } & \multicolumn{3}{|c|}{ Skeletal malocclusion, N (\%) } & \multirow{2}{*}{ P-value } \\
\cline { 2 - 4 } & Class I & Class II & Class III & \\
\hline Without tooth agenesis & $199(62.4)$ & $87(27.3)$ & $33(10.3)$ & Reference \\
\hline All types of tooth agenesis & $20(71.4)$ & $3(10.7)$ & $5(17.9)$ & 0.11 \\
\hline Type of congenitally missing tooth \\
\hline Premolar agenesis & $8(61.5)$ & $1(7.7)$ & $4(30.8)$ & $0.039^{\text {a }}$ \\
\hline Upper lateral incisor agenesis & $9(69.2)$ & $2(15.4)$ & $2(15.4)$ & 0.597 \\
\hline Others tooth agenesis & $4(100)$ & $0(0)$ & $0(0)$ & 0.302 \\
\hline Affected arch & $15(68.2)$ & $3(13.6)$ & $4(18.2)$ & 0.256 \\
\hline Maxillary tooth agenesis & $7(63.6)$ & $1(9.1)$ & $3(27.3)$ & 0.127 \\
\hline Mandible tooth agenesis
\end{tabular}



$\mathrm{N}=$ number.

All comparisons were performed with the group without tooth agenesis. Others tooth agenesis was represented by two cases of molar agenesis and two cases of lower incisor agenesis. 
Table 3. Cephalometric measurements distribution according to the group

\begin{tabular}{c|c|c|c}
\hline Measurements & $\begin{array}{c}\text { Without tooth agenesis } \\
\text { Mean (SD) }\end{array}$ & $\begin{array}{c}\text { Tooth agenesis } \\
\text { Mean (SD) }\end{array}$ & P-value \\
\hline SNA & $81.54(3.89)$ & $81.26(3.62)$ & 0.71 \\
\hline SNB & $78.66(3.79)$ & $79.58(3.59)$ & 0.21 \\
\hline ANB & $2.86(2.49)$ & $1.66(2.52)$ & $0.01^{\mathrm{a}}$ \\
\hline
\end{tabular}

a'Statistically significance difference $(\mathrm{P}<0.05)$, Student's t-test. $\mathrm{SNA}=$ angle between the sella, nasion and subspinale point $\mathrm{A}$; $\mathrm{SNB}=$ angle between the sella, nasion and supramentale point $\mathrm{B}$; $\mathrm{ANB}=$ angle between subspinale point $\mathrm{A}$, nasion and supramentale point $\mathrm{B} ; \mathrm{SD}=$ standard deviation.

missing teeth. The ANB angle had a negative correlation with the number of congenitally missing teeth $(\mathrm{P}=0.039 ; \mathrm{r}=-0.39)$ (Figure 1$)$.

\section{DISCUSSION}

Some researches in dental development have been focused in the understanding of the aetiology of the tooth agenesis. In the past few years much progress has been made to identify the developmental basis of tooth formation $[\underline{19}, \underline{20}]$. Tooth agenesis has been associated with other developmental dental anomalies $[3,21]$, non-syndromic oral cleft [22-24], cancer $[\underline{25}, \underline{26}]$, and specifics craniofacial morphologies $[\underline{17}, \underline{27}, \underline{28}]$. These association studies suggested that, in some instances, tooth agenesis and these conditions presented a similar genetic background.

Skeletal Class III malocclusion has been associated with tooth agenesis $[\underline{8}, \underline{9}, \underline{11}, 17]$, which corroborates with present study that found an association between smaller value of the ANB angle and tooth agenesis. This association led us to raise the hypothesis that, in some instances, the same genes are involved in the aetiology of the both conditions.

Although there is some evidence of the genetic component in the aetiology of non-syndromic tooth agenesis $[\underline{7}, \underline{25}, \underline{29}, \underline{30}, \underline{31-33}]$ and skeletal Class III [ㅍ39], there are no studies that evaluated the genetic aetiology of this condition. In the past two decades, genetic polymorphisms in some genes have been extensively studied in the tooth agenesis context. Genetic variations in growth factors including FGF3, FGF10, and FGFR2 [25], FGFR1 [40], BMP2 [7], BMP4 [31, 33] and TGFb1 [32] have been associated with non-syndromic tooth agenesis. These growth factors genes have been implicated in the regulation of diverse developmental events, including tooth development and are also possibly involved in the mandible/maxilla growth and development.



Figure 1. Correlation between subspinale point $\mathrm{A}$, nasion and supramentale point $\mathrm{B}$ angle and the number of congenitally missing teeth.

An interesting finding observed in this study is that the number of congenitally missing teeth was negatively correlated with the ANB angle measurements. Previous studies also observed that severe forms of tooth agenesis are associated with skeletal Class III $[\underline{8}, 11]$, in which each additional congenitally missing tooth decreases the ANB angle [11]. These findings suggested that the same aetiological factors involved in severe cases tooth agenesis establishment are involved in the mandible/ maxilla development.

In the evaluation according to the type of congenitally missing teeth, there is a preferential association between premolar agenesis and the tendency towards skeletal Class III malocclusion. It is important to emphasize that genetic studies performed in patients with non-syndromic tooth agenesis observed that some genes are involved only in the aetiology of premolar agenesis [9]. Based on these findings, it can be hypothesize that these genes are involved in the mandible and/or maxilla development.

Since different types of congenitally missing teeth have a different genetic aetiology, studies should attempt to the type of affected teeth. In a Turkish population, third molar agenesis was associated with skeletal Class III malocclusion [12]. In the present study, the third molar agenesis was excluded due the young age of the included population.

A study by Hirukawa et al. [41] suggested that maxillary tooth agenesis might be involved in the skeletal Class III malocclusion, while Kreczi et al. [42] stated that tooth agenesis may have a negative influence on the sagittal development of a jaw. In the present study, there was no preferential association according to the dental arch. This might be explained by small sample size of this study, but it is also possible that the difference according to the dental arch does not exist. 


\section{CONCLUSIONS}

Tooth agenesis is associated with a smaller subspinale point $\mathrm{A}$, nasion and supramentale point $\mathrm{B}$ angle, which is correlated with number of congenitally missing teeth. The results also suggest that premolar agenesis is involved with Class III malocclusion.

\section{ACKNOWLEDGMENTS AND DISCLOSURE STATEMENTS}

The authors have no conflicts of interest to declare. Support for this work was provided by CAPESCoordination for the Improvement of Education Personnel (Ana Maria Guerra Costa, Mariana Trevizan and Karla Carpio Horta fellowship) and FAPESP - The São Paulo Research Foundation (Erika Calvano Küchler).

\section{REFERENCES}

1. Vastardis $\mathrm{H}$. The genetics of human tooth agenesis: new discoveries for understanding dental anomalies. Am J Orthod Dentofacial Orthop. 2000 Jun;117(6):650-. [Medline: 10842107] [doi: 10.1067/mod.2000.103257]

2. Vastardis $\mathrm{H}$. The genetics of human tooth agenesis: new discoveries for understanding dental anomalies. Am J Orthod Dentofacial Orthop. 2000 Jun;117(6):650-. [Medline: 18771513] [doi: 10.1111/j.1600-0714.2008.00699.x]

3. Küchler E, De Andrade Risso P, De Castro Costa M, Modesto A, Vieira AR. Assessing the proposed association between tooth agenesis and taurodontism in 975 paediatric subjects. Int J Paediatr Dent. 2008 May;18(3):231-4. [Medline: 18384350] [doi: 10.1111/j.1365-263X.2007.00876.x]

4. Küchler EC, Risso PA, Costa Mde C, Modesto A, Vieira AR. Studies of dental anomalies in a large group of school children. Arch Oral Biol. 2008 Oct;53(10):941-6. [Medline: 18490001] [doi: 10.1016/j.archoralbio.2008.04.003]

5. Polder BJ, Van't Hof MA, Van der Linden FP, Kuijpers-Jagtman AM. A meta-analysis of the prevalence of dental agenesis of permanent teeth. Community Dent Oral Epidemiol. 2004 Jun;32(3):217-26. [Medline: 15151692] [doi: 10.1111/j.1600-0528.2004.00158.x ]

6. Acevedo AC, Poulter JA, Alves PG, de Lima CL, Castro LC, Yamaguti PM, Paula LM, Parry DA, Logan CV, Smith $\mathrm{CE}$, Johnson CA, Inglehearn CF, Mighell AJ. Variability of systemic and oro-dental phenotype in two families with non-lethal Raine syndrome with FAM20C mutations. BMC Med Genet. 2015 Feb 21;16:8. [Medline: 25928877] [PMC free article: 4422040] [doi: 10.1186/s12881-015-0154-5]

7. Lu Y, Qian Y, Zhang J, Gong M, Wang Y, Gu N, Ma L, Xu M, Ma J, Zhang W, Pan Y, Wang L. Genetic Variants of BMP2 and Their Association with the Risk of Non-Syndromic Tooth Agenesis. PLoS One. 2016 Jun 30;11(6):e0158273. [Medline: 27362534] [PMC free article: 4422040] [doi: 10.1371/journal.pone.0158273]

8. Chung LK, Hobson RS, Nunn JH, Gordon PH, Carter NE. An analysis of the skeletal relationships in a group of young people with hypodontia. J Orthod. 2000 Dec;27(4):315-8. [Medline: 11099569] [doi: 10.1093/ortho/27.4.315]

9. Chan DW, Samman N, McMillan AS. Craniofacial profile in Southern Chinese with hypodontia. Eur J Orthod. 2009 Jun;31(3):300-5. [Medline: 19193707] [doi: 10.1093/ejo/cjn111]

10. Uslu O, Akcam MO, Evirgen S, Cebeci I. Prevalence of dental anomalies in various malocclusions. Am J Orthod Dentofacial Orthop. 2009 Mar;135(3):328-35. [Medline: 19268831] [doi: 10.1016/j.ajodo.2007.03.030]

11. Acharya PN, Jones SP, Moles D, Gill D, Hunt NP. A cephalometric study to investigate the skeletal relationships in patients with increasing severity of hypodontia. Angle Orthod. 2010 Jul;80(4):511-8. [Medline: 20482356] [doi: $10.2319 / 072309-411.1]$

12. Celikoglu M, Kazanci F, Miloglu O, Oztek O, Kamak H, Ceylan I. Frequency and characteristics of tooth agenesis among an orthodontic patient population. Med Oral Patol Oral Cir Bucal. 2010 Sep 1;15(5):e797-801. [Medline: 20383097] [doi:10.4317/medoral.15.e797]

13. Kim YH. Investigation of hypodontia as clinically related dental anomaly: prevalence and characteristics. ISRN Dent. 2011;2011:246135. [Medline: 21991459] [PMC free article: 3170076] [doi: 10.5402/2011/246135]

14. Al-Amiri A, Tabbaa S, Preston CB, Al-Jewair T. The prevalence of dental anomalies in orthodontic patients at the State University of New York at Buffalo. J Contemp Dent Pract. 2013 May 1;14(3):518-23. [Medline: 24171999]

15. Hedayati Z, Dashlibrun YN. The prevalence and distribution pattern of hypodontia among orthodontic patients in Southern Iran. Eur J Dent. 2013 Sep;7(Suppl 1):S78-82. [Medline: 24966733] [doi: 10.4103/1305-7456.119080]

16. Ota K, Arai K. Prevalence and patterns of tooth agenesis in Angle Class II Division 2 malocclusion in Japan. Am J Orthod Dentofacial Orthop. 2015 Jul;148(1):123-9. [Medline: 26124035] [doi: 10.1016/j.ajodo.2015.02.023]

17. Cocos A, Halazonetis DJ. Craniofacial shape differs in patients with tooth agenesis: geometric morphometric analysis. Eur J Orthod. 2016 Jul 27. pii:cjw049. [Medline: 27464525] [doi: 10.1093/ejo/cjw049]

18. Pedreira FR, de Carli ML, Pedreira Rdo P, Ramos Pde S, Pedreira MR, Robazza CR, Hanemann JA. Association between dental anomalies and malocclusion in Brazilian orthodontic patients. J Oral Sci. 2016;58(1):75-81. [Medline: 27021543] [doi: $10.2334 /$ josnusd.58.75] 
19. Cobourne MT. The genetic control of early odontogenesis. Br J Orthod. 1999 Mar;26(1):21-8. [Medline: 10333884] [doi: 10.1093/ortho/26.1.21]

20. Chhabra N, Goswami M, Chhabra A. Genetic basis of dental agenesis--molecular genetics patterning clinical dentistry. Med Oral Patol Oral Cir Bucal. 2014 Mar 1;19(2):e112-9. [Medline: 24121910] [PMC free article: 4015040] [doi: $10.4317 /$ medoral.19158]

21. AlShahrani I, Togoo RA, AlQarni MA. A review of hypodontia: Classification, prevalence, etiology, associated anomalies, clinical implications and treatment options. World J Dent. 2013 April;4(2):117-25. [doi: 10.5005/jp-journals-10015-1216]

22. Shapira Y, Lubit E, Kuftinec MM. Hypodontia in children with various types of clefts. Angle Orthod. 2000 Feb;70(1): 16-21. [Medline: 10730671] [doi: 10.1043/0003-3219(2000)070<0016:HICWVT>2.0.CO;2]

23. Letra A, Menezes R, Granjeiro JM, Vieira AR. Defining subphenotypes for oral clefts based on dental development. J Dent Res. 2007 Oct;86(10):986-91. [Medline: 17890676] [PMC free article: 2222667] [doi: 10.1177/154405910708601013]

24. Küchler EC, da Motta LG, Vieira AR, Granjeiro JM. Side of dental anomalies and taurodontism as potential clinical markers for cleft subphenotypes. Cleft Palate Craniofac J. 2011 Jan;48(1):103-8. [Medline: 20507240] [doi: 10.1597/09-159]

25. Küchler EC, Lips A, Tannure PN, Ho B, Costa MC, Granjeiro JM, Vieira AR. Tooth agenesis association with self-reported family history of cancer. J Dent Res. 2013 Feb;92(2):149-55. [Medline: 23169889] [doi: 10.1177/0022034512468750]

26. Fekonja A, Cretnik A, Zerdoner D, Takac I. Hypodontia phenotype in patients with epithelial ovarian cancer. Radiol Oncol. 2015 Mar 3;49(1):65-70. [Medline: 25810703] [PMC free article: 4362608] [doi: 10.2478/raon-2014-0034]

27. Chung CJ, Han JH, Kim KH. The pattern and prevalence of hypodontia in Koreans. Oral Dis. 2008 Oct;14(7):620-5. [Medline: 18248591] [doi: 10.1111/j.1601-0825.2007.01434.x]

28. Al-Jabaa AH, Aldrees AM. Prevalence of dental anomalies in Saudi orthodontic patients. J Contemp Dent Pract. $2013 \mathrm{Jul}$ 1;14(4):724-30. [Medline: 24309355] [doi: 10.5005/jp-journals-10024-1391]

29. Vastardis H, Karimbux N, Guthua SW, Seidman JG, Seidman CE. A human MSX1 homeodomain missense mutation causes selective tooth agenesis. Nat Genet. 1996 Aug;13(4):417-21. [Medline: 8696335] [doi: 10.1038/ng0896-417]

30. Vieira AR, Modesto A, Meira R, Barbosa AR, Lidral AC, Murray JC. Interferon regulatory factor 6 (IRF6) and fibroblast growth factor receptor 1 (FGFR1) contribute to human tooth agenesis. Am J Med Genet A. 2007 Mar 15;143A(6):538-45. [Medline: 17318851] [PMC free article: 2570343] [doi: 10.1002/ajmg.a.31620]

31. Antunes LS, Küchler EC, Tannure PN, Costa MC, Gouvêa CV, Olej B, Granjeiro JM. BMP4 Polymorphism is Associated With Nonsyndromic Oral Cleft in a Brazilian Population. Cleft Palate Craniofac J. 2013 Nov;50(6):633-8. [Medline: 23237431] [doi: 10.1597/12-048]

32. Zhang W, Qu HC, Zhang Y. Association of MSX1 and TGF- $\beta 1$ genetic polymorphisms with hypodontia: meta-analysis. Genet Mol Res. 2014 Nov 28;13(4):10007-16. [Medline: 25501212] [doi: 10.4238/2014.November.28.5]

33. Gong M, Qian YJ, Gu N, Wang W, Wang H, Ma L, Ma JQ, Zhang WB, Pan YC, Wang L. Association of BMP4 polymorphisms with isolated tooth agenesis in a Chinese Han population: a case-control study. Eur Rev Med Pharmacol Sci. 2015 Jun;19(12):2188-94. [Medline: 26166641]

34. Yamaguchi T, Maki K, Shibasaki Y. Growth hormone receptor gene variant and mandibular height in the normal Japanese population. Am J Orthod Dentofacial Orthop. 2001 Jun;119(6):650-3. [Medline: 11395710] [doi: 10.1067/mod.2001.114536]

35. Tomoyasu Y, Yamaguchi T, Tajima A, Nakajima T, Inoue I, Maki K. Further evidence for an association between mandibular height and the growth hormone receptor gene in a Japanese population. Am J Orthod Dentofacial Orthop. 2009 Oct;136(4):536-41. [Medline: 19815155] [doi: 10.1016/j.ajodo.2007.10.054]

36. Kang EH, Yamaguchi T, Tajima A, Nakajima T, Tomoyasu Y, Watanabe M, Yamaguchi M, Park SB, Maki K, Inoue I. Association of the growth hormone receptor gene polymorphisms with mandibular height in a Korean population. Arch Oral Biol. 2009 Jun;54(6):556-62. [Medline: 19344888] [doi: 10.1016/j.archoralbio.2009.03.002]

37. Tassopoulou-Fishell M, Deeley K, Harvey EM, Sciote J, Vieira AR. Genetic variation in myosin 1H contributes to mandibular prognathism. Am J Orthod Dentofacial Orthop. 2012 Jan;141(1):51-9. [Medline: 22196185] [PMC free article: 3600843] [doi: 10.1016/j.ajodo.2011.06.033]

38. Chen F, Li Q, Gu M, Li X, Yu J, Zhang YB. Identification of a Mutation in FGF23 Involved in Mandibular Prognathism. Sci Rep. 2015 Jun 10;5:11250. [Medline: 26059428] [PMC free article: 4462018] [doi: 10.1038/srep11250]

39. da Fontoura CS, Miller SF, Wehby GL, Amendt BA, Holton NE, Southard TE, Allareddy V, Moreno Uribe LM. Candidate Gene Analyses of Skeletal Variation in Malocclusion. J Dent Res. 2015 Jul;94(7):913-20. [Medline: 25910506] [PMC free article: 4530344] [doi: 10.1177/0022034515581643]

40. Ruprecht A, Batniji S, Sastry KA, el-Neweihi E. The incidence of dental invagination. J Pedod. 1986 Spring;10(3):265-72. [Medline: $\underline{3459853}$ ]

41. Hirukawa K, Iwata R, Kurosawa M, Kondo T, Goto S. Statistical investigation about the prevalence of congenitally missing permanent teeth. Orthod Waves. 1999; 58:49-56.

42. Kreczi A, Proff P, Reicheneder C, Faltermeier A. Effects of hypodontia on craniofacial structures and mandibular growth pattern. Head Face Med. 2011 Dec 6;7:23. [Medline: 22142280] [PMC free article: 3248361] [doi: 10.1186/1746-160X-7-23] 


\section{To cite this article:}

Costa AMG, Trevizan M, Matsumoto MAN, da Silva RAB, da Silva LAB, Horta KC, Romano FL, Nelson-Filho P, Küchler EC.

Association between Tooth Agenesis and Skeletal Malocclusions

J Oral Maxillofac Res 2017;8(2):e3

URL: http://www.ejomr.org/JOMR/archives/2017/2/e3/v8n2e3.pdf

doi: $\underline{10.5037 / \text { jomr.2017.8203 }}$

Copyright (C) Costa AMG, Trevizan M, Matsumoto MAN, da Silva RAB, da Silva LAB, Horta KC, Romano FL, Nelson-Filho P, Küchler EC. Published in the JOURNAL OF ORAL \& MAXILLOFACIAL RESEARCH (http://www.ejomr.org), 30 June 2017.

This is an open-access article, first published in the JOURNAL OF ORAL \& MAXILLOFACIAL RESEARCH, distributed under the terms of the Creative Commons Attribution-Noncommercial-No Derivative Works 3.0 Unported License, which permits unrestricted non-commercial use, distribution, and reproduction in any medium, provided the original work and is properly cited. The copyright, license information and link to the original publication on (http://www.ejomr.org) must be included. 